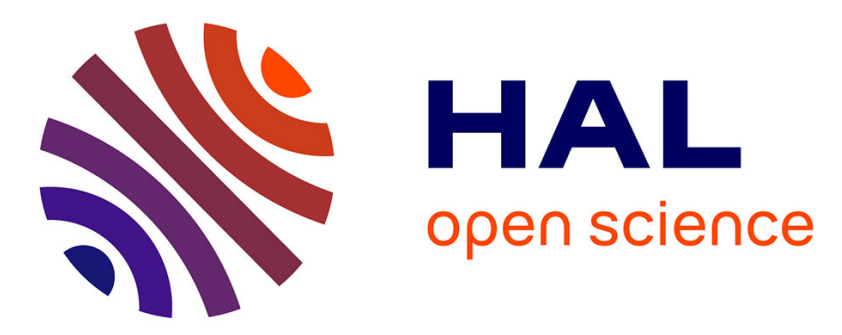

\title{
Understanding the diversity and complexity of demand for microfinance services: lessons from informal finance
}

\author{
Isabelle - Guérin, Jean-Michel - Servet, Morvant-Roux Solène
}

\section{To cite this version:}

Isabelle - Guérin, Jean-Michel - Servet, Morvant-Roux Solène. Understanding the diversity and complexity of demand for microfinance services: lessons from informal finance . Armendariz B. \& Labie M. Handbook of microfinance, World Scientific Publishing, pp. 101-122, 2011. ird-01415384

\author{
HAL Id: ird-01415384 \\ https://hal.ird.fr/ird-01415384
}

Submitted on 13 Dec 2016

HAL is a multi-disciplinary open access archive for the deposit and dissemination of scientific research documents, whether they are published or not. The documents may come from teaching and research institutions in France or abroad, or from public or private research centers.
L'archive ouverte pluridisciplinaire HAL, est destinée au dépôt et à la diffusion de documents scientifiques de niveau recherche, publiés ou non, émanant des établissements d'enseignement et de recherche français ou étrangers, des laboratoires publics ou privés. 


\title{
Understanding the Diversity and Complexity of Demand for Microfinance Services: Lessons from Informal Finance
}

\author{
Isabelle Guérin \\ Research Unit "Development and Societies" \\ (Institute of Research for Development/Paris I-La Sorbonne), \\ Project Leader "Microfinance and Employment: \\ Do Processes Matter?" (RUME), and CERMi \\ Solène Morvant-Roux \\ Institut de Recherche pour le Développement (IRD), \\ Rural Microfinance and Employment (RUME), and CERMi \\ Jean-Michel Servet \\ Graduate Institute (Genèva), \\ Institut de Recherche pour le Développement \\ (UMR 201 Paris 1), and CERMi
}

There is growing consensus that microfinance supply is too standardised, inflexible and inadequate given the diversity of financial needs. As a result, microfinance is a very partial substitute for informal financial services and their comparative advantages.

This paper aims to deepen understanding of financial service demand by learning from informal finance. Based on economic anthropology, our analysis shows that microfinance does not substitute informal finance for many reasons: because money and informal finance are multidimensional and context specific; because the boundary between saving and borrowing is blurred; because money circulates in small quantities and quickly in village economies; because informal finance is more flexible; and, last but not least, because informal finance is a vector of social inclusion. 
The first part proposes a general analytical framework for understanding the social dimension of money, debt and saving. The second part describes some fundamental mechanisms of informal finance, whilst the third part uses this analytical framework to understand how people appropriate microfinance.

\section{The Social Meaning of Money, Debt and Saving}

Money is the economic object of study par excellence; the great equalizer, money is considered a means of individualization, destroyer of hierarchies, obliterator of statutory privileges. The fundamental role of money, defined as a unit of calculation and a standardised means of payment, is ostensibly to create contractual relationships between equals. But ethnological and historical analysis of monetary practices reveals that money's impersonality and anonymity is illusory (Baumann et al., 2008; Bazin and Selim, 2002; Guyer, 1995; Villarreal, 2004; Bloch and Parry, 1989; Zelizer, 1994, 2005; Servet, 1984, 2006). Money, and the practices stemming from it, are above all a social construct. Money is embedded in preexisting relationships governed by rights and obligations; relationships it can influence, but never destroy.

\subsection{Money: A source of tension between the individual and the group}

Money and finance are social institutions in that their access and use depends on conventions, norms and formal rules (Commons, 1989; Polanyi, 1968; Servet, 1984, 2006). Consequently, money is characterised by a permanent tension between the individual and the group, between personal aspirations and collective responsibilities. This ongoing tension takes several forms:

- Although economists generally define saving and indebtedness in terms of time, with the purpose of securing material gain, finance is often $a$ means of relating to the group or creating interpersonal bonds of dependence and domination. When individual behaviours are not reduced solely to their economic dimension, going into debt or lending money is a sign of social inclusion. Indebtedness and saving reinforces a sense of social belonging, whether characterized by domination, dependence or equality. As a result, in some societies, it is important for money to change hands quickly. The poor often accumulate debt and credit and repay loans according to their own informal hierarchies (Shipton, 2007) 
and frameworks of calculation (Villarreal, 2004). Such phenomena transcend material or self-centred motivations and reflect issues of status, honour, power, and individual and group identity.

- Hoarding goes directly against the rationale that money must change hands, which is why non-monetary saving practices are so common, whether in kind or in the form of exchanges or loans to others. This same rationale explains why people tend to rank savings possibilities not only in terms of security but social considerations.

- The social dimension of finance does not preclude financial reasoning, in the economic sense of the term. Quite the opposite. The poor more than anyone need to keep accounts, calculate and anticipate. But they are not necessarily sensitive to the same criteria, constraints or rationale that apply to the wealthy. Interest rates, for example, are often addressed in a Manichean manner ("Are the poor sensitive or not to high interest rates?"). In fact, there are many ways to interpret interest rates. Some vernacular languages have no specific terms to designate the surplus a debtor pays a lender. In such cases, debt is seen not in relationship to time but in terms of commercial margin (Baumann, 1998) or as a fee (Collins et al., 2009).

- Financial transactions imply inclusion in one or more social groups, but the nature of this affiliation is far from simple. Not only can an individual belong to several social groups, ranging from the customary (family, ethnicity, caste, gender, religion) to the constructed (professional, neighbourhood, associative groupings), but membership is constantly evolving. The variety and vibrancy of financial practices reflect this diversity.

- Understanding financial behaviours requires a temporal perspective. There are immediate needs associated with daily survival, needs associated with life-cycle events, needs associated with social and religious rituals, and needs that are investments over a lifetime or even several generations.

The claim that microfinance clients are "financially excluded" and in need of financial inclusion and money management skills only holds true from a formal sector standpoint. Take into account informal finance, and it becomes altogether dubious.

\subsection{Informal finance: Diverse practices and landscapes}

Informal finance has kept pace with the monetarisation and financialisation of contemporary societies (Servet, 2006), remaining vibrant and 
extraordinarily diverse. Indeed, the term "informal finance" — with its monolithic connotation - is almost meaningless: it makes more sense to refer to informal financial practices instead. Because informal financial practices evolve with society, ${ }^{1}$ they are as diverse as the social settings where they are found. Their social embeddedness makes them consistently distinctive, their diversity a tribute to humankind's imaginative and adaptive capacities.

Informal finance takes many forms, both collective and individual. Examples include rotating savings and credit associations (ROSCAs) and community organisations designed to cover funeral costs, collective celebrations or large community projects.

A multitude of private intermediaries also exist. We now know that the cliché of exploitative and greedy usurers, a caricature much-favoured by the media, decision makers and many MFIs, does not stand up to factual analysis. Professional lenders are only one category of a mosaic of lenders. First, there is the inner circle of neighbours, friends and family, probably used everywhere to varying degrees. The principles of solidarity and reciprocity prevail in such exchanges, organised such that everyone takes their turn as debtor and creditor.

Next, there are individuals who lend by virtue of their status or privileged access to cash. These include private specialised lenders, pawnbrokers, shopkeepers who accord credit, traders who pay for harvests in advance, manual labourer employers or recruiters who advance payment, and salespeople who sell goods on credit and then immediately buy them back for less. Also in this category are wholesalers who sell on credit to small shopkeepers, artisans or travelling vendors, and employers who lend to former apprentices wanting to start their own activity. Local elites - landowners, employers, teachers, civil servants, migrants or migrants' wives, local elected officials, religious leaders, doctors - may also wish to invest liquidity surpluses and/or extend their social network.

There are also those who safeguard money. Some are mobile and make house calls. Others have shops or simply belong to the saver's social network. Often, savings collectors are a more secure alternative to hoarding.

The prevalence and complementarily of these informal practices varies across regions and cultures according to legal, technical, cultural and social

\footnotetext{
${ }^{1}$ Before almost universal salarisation took place, informal financial ties were extremely common in European societies (Fontaine, 2008).
} 
constraints. Hence the expression 'financial landscape' (Bouman, 1994), which seeks to account for the diversity and interconnectedness of different practices even between the so-called formal financial sector and informal financial practices.

Indeed, most societies do not function in terms of financial dualism, with the formal sector on one side and the informal on the other. People often move fluidly between the two, not only the poor, but middle and high-income populations as well.

The diversity of so-called "informal financial practices" stems from all these elements combined: the social embeddedness of money, multiple group affiliation, the permanent tension between the individual and the group, and evolution of financial needs throughout the life-cycle. These elements help better understand how people perceive finance in their daily life, whether in the context of credit, saving or risk management. They also shed light on how people appropriate financial services offered by outsiders, and in particular microfinance institutions.

\section{In What Ways Do People Perceive and Experience Finance?}

Analysing so-called informal finance practices brings to light la pensée sauvage (the savage mind) - to employ Lévi-Strauss's expression — with respect to money, debt and saving. It reveals conventions, habits and local categories of thought, i.e., the ways people perceive and use finance.

\subsection{Saving and credit: A false dichotomy}

For a long time, the "poor" were considered incapable of saving. While it is true that monetary hoarding is often limited, there is no doubt the poor do save to protect themselves from future risk and anticipate certain expenses (Collins et al., 2009; Lelart, 1990; Rutherford, 2001; Servet, 1996). These include recurring expenditures (school fees, religious festivals) and life-cycle costs (housing, birth, coming of age ceremonies, marriages, funerals, pilgrimages, etc.). On the other hand, their savings options - and the criteria they use to assess them - vary. Reasons for saving are also diverse and sometimes contradictory, given the permanent tension between social obligations and individual desires. The result is a plethora of complementary practices, sometimes impossible to substitute. 
What accounts for the decision to use a particular form of saving? The following list is neither exhaustive nor definitive, reflecting only tendencies observed in several regions of the world. The importance of each factor varies according to context, social groups and individual behaviours.

- Security/thrift: saving's primary function. Goods acting as a form of saving must be able to be stored safely without risk of degradation or depreciation.

- Access to liquidity: in urgent need, cash should be quickly and easily accessible.

- Social identity: some acts of saving are more an expression of one's social identity than an individual act.

- Anonymity and discretion: when saving is for a personal project, anonymity and discretion come into play. Even in families where individual members pool part of their income for common expenses, individuals often have savings practices and networks of their own. The desire for discretion is particularly great amongst women, who often seek to preserve a space, however tiny, for themselves, free from male intervention.

- Illiquidity and incentives: saving is difficult not only because cash is short and income irregular; the poor often face pressure to spend. Torn by the demands from family members and a constantly needy entourage, people often say that cash "burns their fingers". Given this pressure, families often look for mechanisms which incite, or even force them to save. $^{2}$ This need can be so pressing that people are prepared to pay to save: hence the success of itinerant savings collectors in many countries. The same logic holds true for ROSCA members who prefer to receive their sum at the end of the cycle. To account for the tensions created by the ongoing balancing act between liquidity and illiquidity, individualism and group responsibility, Shipton (1995) conceptualizes this mechanism as the "squawk factor" which he describes in the Gambian context: "[... saving strategies are mainly concerned with removing wealth from the form of readily accessible cash without appearing antisocial" (Shipton, 1995: 257).

\footnotetext{
${ }^{2}$ This type of behaviour was studied by anthropologists in the 1980s and 1990s (see, for example, Guyer (1995), Shipton (1995). Over the last few years, an increasing number of economists have been looking at this "preference for illiquidity". See for instance Bauer et al. (2008). See also Collins et al. (2009), Vonderlack \& Schreiner (2002), Guérin (2006).
} 
- Speculation: "Money needs to multiply", declare Indian women, explaining their membership in seetu (ROSCAs) or gold purchases. Similar ideas can be found in the practices of Cameroonian tontines or Chinese hui. Speculation often explains the preference for saving forms likely to appreciate over time, such as precious metals, cereals or cattle.

While saving forms vary from one context to another, monetary hoarding is a rarity. This is as much a question of safety as it is an effort to resist the temptation to spend and to ward off requests from one's entourage; furthermore, immobilized money serves no purpose. In the English language and particularly in the work of David Riccardo, the term "circulation" is used in reference to money. Indeed in Senegal, money is often said to "burn", it circulates so quickly (Guérin, 2003). Women frequently joke about the way money circulates without stopping: "Money, yes, we see a lot of it, but it never stays still for long". "As soon as it arrives, it leaves." No sooner is it received, it is spent, released into the community as an "investment", the women's choice of term - liable to be recovered at any moment in the case of "pressing need" or "problem". To the question "do you save?", it is common for people to sincerely reply that they lend; it is considered a form of savings. In the indigenous communities of Mexico, all forms of wealth (not only coins and notes but also bricks, food products or cattle) may be loaned if the owner does not have an immediate need for them (Morvant-Roux, 2009). Shipton (1995) has made the same observation in rural Gambia, where the slightest riches, whether in cash or in kind, are loaned to conceal ownership and cement social bonds.

The logic of constant circulation of debt and credit is neither exotic nor archaic and the blurring of savings and loans is found throughout the world (Guyer, 1995; Lont and Hospes, 2004). In fact, borrowing is simply a means to force oneself to save in the future (Rutherford, 2001), just as lending is a form of saving that presupposes the right to borrow later. Microfinance institutions are but one of many strategies clients use when juggling various formal and informal finance opportunities accessible.

\subsection{ROSCAs: Individual projects and collective constraints}

ROSCAs are a common financial form that exemplify the melding of saving and credit simultaneously. ROSCAs exist around the world, but their modalities, function and nomenclature are specifically local. A vast body of literature confirms their extraordinary diversity and capacity to adapt to very 
different and rapidly evolving environments (Ardener, 1964; Ardener and Burman, 1996; Bouman, 1977; Servet, 1995; Lelart, 1990, 2005). However, the success of ROSCAs probably stems largely from their ability to address individual financial constraints collectively (Servet, 1996). Hence the low rates of default as members force themselves to make regular payments.

Members who receive their sum early in the cycle essentially receive uncollateralized loans from the others. If a debtor stops paying his or her share, s/he may be banished from the community, thus the importance of carefully selecting members, or at least the organiser. The organiser is responsible for defaulting members, even if this means tracking down the defaulter, or calling on the police and courts. This is where group and individual rationales intersect. The organiser must ensure the ROSCA's proper functioning while exercising his/her power to ensure the defaulter eventually repays. The obligation to pay, to use Marcel Mauss's expression from his famous Essay on the Gift (1950), is stronger than most legal constraints. Not honouring one's word would amount to social suicide. ROSCA members know they must respect their obligations if they want to participate in other tontines or simply extend to other contexts the benefits of solidarity and protection that come with being a member in good standing. In ROSCAs, the act of saving is not about an individual relationship to time but rather a social relationship where reciprocal obligations are bound and unbound (Lelart, 1990; Baumann, 2003).

The subtle balance between individual and group needs takes other forms. ROSCAs permit members to ward off loan requests from family members, whilst still allowing them, at least in some cases, to respect social obligations (pilgrimages, ceremonies, support family members, etc.). In broad terms, ROSCAs express and contribute to the restructuring of social relationships. Indeed, various case studies on ROSCAs show how family ties are sometimes used and reinforced, but also avoided, substituted or even weakened, depending on the region and community (Ardener, 1995; Guérin, 2006).

\subsection{The circulation of money and juggling practices}

Money is constantly "lacking", but it also circulates with astonishing intensity. The tendency to take on debt clearly arises from a mismatch between income and expenses, but it is also a matter of maintaining credibility, one's reputation and social networks. Lending presupposes the two parties already share a relationship of trust, but it also serves to maintain, reinforce and renew this relationship. 
When describing their financial practices, Senegalese women state: "Sab bukki, sulli bushidô" (take a hyena, bury a hyena) or "sab-sul" (dig and bury), meaning they take new debt to pay off old debt. They also speak of "drawers", whereby all the people or groups they lend to or do a favour for represent a "drawer" they can pull at any moment. In Mexico, Magdalena Villarreal describes women's credit chains, in which any income is largely used to repay old debts, to maintain credibility and thus borrow again later (Villarreal, 2002). Morvant-Roux (2006) demonstrates how in rural Mexico, more than a third of 239 interviewees were concurrently indebted to at least two distinct financial sources.

Permanent juggling practices should not always be understood as a sign of over-indebtedness or poor management. In many cases, they reflect deliberate choices and strategies geared to multiply and reinforce social relationships and maintain a certain balance, considering the inherent ambiguity of all debt relations. Ambiguous, because while debt is a source of protection and solidarity, as well as a means of expressing reciprocal trust and respect, when it is not honoured or is too imbalanced, it can be a source of humiliation, shame, exploitation and servitude. It is both a lifeline and a death knot, to employ the expression of Charles Malamoud (1980). Marcel Mauss speaks of gift as the "poison", which he assimilates to a form of loan. Hence the subtle game to regularly reduce one's debt whilst taking on debt elsewhere.

"Saving-loans" are always reciprocated (the lender eventually becomes the borrower and vice versa) and address both short-term survival needs and long-term social ones, like religious rituals, marriage, puberty or godparenting ceremonies, annual festivals or funerals. The exchange may take the form of cash or goods with social and symbolic value: jewels, clothing (pagnes in Senegal, sarees in India) or animals (cows among the Fulbe in Sub-Saharan Africa, pigs in Papua New Guinea and also in certain tribes in India (Thanuja, 2005), turkeys in Mexico (Morvant, 2006)).

\subsection{Flexibility and negotiability}

Many studies on how populations compare financial services have highlighted the importance of "negotiability", defined as the possibility to negotiate transaction modalities and, particularly, defer repayment deadlines (Rutherford, 2001; Johnson, 2004; Servet, 2006).

Negotiability is important for two reasons. The possibility to adapt repayments to irregular incomes and expenses is a key advantage, particularly if income fluxes are seasonal and uncertain (as in agricultural 
production or migration). But negotiability is also a way to personalise a social relationship.

The principle of standardised prices and terms allows for a contractual relationship between equals. The principle of negotiability, in contrast, expresses a personal relationship: here, the nature of the relationship and the relative statuses of the two parties influence the terms of the exchange. Anthropological literature has shown the extent to which not fixing prices a priori is standard practice (Bloch and Parry, 1989). What at first glance appears to be a lack of transparency is ultimately a form of protection against the anonymity of a commercial relationship in which the same price and terms apply to everyone (Toren, 1989). In Africa, during the second half of the 20th, century, Sarah Berry (1995) demonstrates that negotiability responds to two sources of major uncertainties: uncertainty linked to economic crisis and hyperinflation, but also uncertainty linked to the redefinition of the notion of "value", status, hierarchies and identities as a result of monetarisation and "modernisation" (education, migration). There is no shortage of information regarding the allocation of resources and wealth creation; what is lacking is an understanding of the meaning behind this information; after all, the permanent negotiation of prices is first and foremost a negotiation of value.

In Southern India, a study on quality of financial services involving 170 families showed that "negotiability" is the most valued criteria (highlighted by over a third of those interviewed). Next was cost (26 percent) followed by "discretion" (17 percent). Negotiability is a major component of informal finance, and "contracts" between creditors and debtors are often flexible: cost and duration are not always specified at the outset and are likely to evolve over time. Repayment methods can be adapted to the borrowers' or lenders' constraints and the latter may reclaim their due in an emergency. In vertical or hierarchical financial relationships (for instance loans from an employer, a landowner or member of the local elite), the debt relationship is but one component of a larger relationship, which often resembles a form of patronage. The lender's generosity and flexibility demonstrates his or her role as protector, but this protection is "repaid" by material and symbolic compensations (favours or free assistance at a moment's notice, patronage of a shop controlled by the lender, recognition and gratitude). In the case of itinerant lenders, transaction terms vary greatly on the basis of loyalty and trust (not unlike commercial relationships in the West which employ client loyalty strategies). Regular clientele benefit from the best terms (such as low prices or greater flexibility), as do those who act as guarantor for other 
clients - a very common practice, as trust is the main collateral. Benefiting from the best terms is implicit compensation for favours accorded.

Negotiability also applies to the loan amount. Microcredit providers usually demand regular interest payments along with the principal. Some informal private lenders demand only regular interest payments, whilst retaining their rights over the principal. Such arrangements can last several years. The term "rent" is more fitting than "interest" in this kind of financial relationship. As a strategy, it compares to owners renting out a house that they have no interest in selling, even if they sometimes change tenants. What matters is that the balance is periodically paid off. ${ }^{3}$ The way the debt is settled depends on the context, era and nature of the relationship between the creditor and the debtor. Sometimes the debt is never settled and is even passed on to the following generation. Sometimes, it is ultimately cancelled, if the debtor manages to show that the total interest paid is enough (in India, for example, some creditors cancel debt when interest payments represents two or three times the principal). In other cases, the principal is paid back after a few months or years.

Our purpose is not to idealise this personalisation of debt relationships, which can affirm solidarity but also reinforce subordination. Sometimes extreme flexibility or debt cancelation conceals relationships of subjugation and exploitation. Rather, we seek to demonstrate that people perceive finance and manage their finances in this way.

\section{The Role of Informal Financial Practices in the Appropriation of Microfinance}

Analysing informal finance gives us a better understanding of how microfinance is used. Interestingly, the fluid boundaries between saving and lending show up in loan use. For example, clients commonly put aside a portion of microcredit for saving (in the form of liquidity, gold purchases, or loans to others, etc.) ${ }^{4}$ It is not surprising that some MFIs struggle to collect savings: in many cases, informal practices better correspond to people's constraints

\footnotetext{
${ }^{3}$ This analogy has basis in fact. In India, for example, it is possible for a tenant to pay an owner a large sum of money in exchange for the occupation of a house. The owner must return this sum when the tenant leaves the property. If he does not, the tenant can retain possession of the house and can sublet it until the owner repays the debt.

${ }^{4}$ This is common practice in southern India. Sebstad and Cohen (2000) point to the same phenomenon in several regions of the world.
} 
and motivations. Some noteworthy innovations do exist. For short-term saving, SEWA's home savings programme in Gujarat, operating successfully since the 1970s, comes to mind, as does SafeSave in Bangladesh, betting on flexibility and proximity since the 1990s. For long-term saving, SEWA offers saving accounts remunerated in gold. There are probably other innovations worthy of documentation. But much remains to be done to design services adapted to how people perceive saving. Moreover, many informal saving practices are so much more advantageous, that the attempt to substitute is often in vain.

Analysing informal finance also reveals how microcredit is used. Clients do not passively consume microcredit services. They translate and interpret them according to their own frame of reference, adjusting and adapting them, often bypassing the rules to do so. A process of appropriation takes place, both at the individual and collective level (Morvant-Roux, 2006).

\subsection{Borrowing to onlend: Abuse or a normal part of the system?}

Some studies have found clients use microcredit for money lending. Instead of investing in a so-called productive activity or covering a family expense, clients onlend to their entourage, often with interest. MFIs antagonistic to usurers naturally condemn such practices. In our opinion, however, onlending should not be automatically judged as a digression or anomaly of the system, but rather a natural (even rational) outcome.

For example, Perry (2002) has shown that in some rural zones in Senegal, the major impact of microfinance has been to create a new category of informal private lenders: middle class and poor women. The zone studied is characterised by reduced availability of credit due to a slowdown of cooperative banks and landowners moving away from agriculture to go into business and who no longer have liquidity to lend. In contrast, for several years now, microfinance has targeted women. A large number of loans are in fact onlent locally, mostly to the borrowers' extended male kin. Several reasons explain this phenomenon. Productive opportunities are limited and risky (entry barriers, weak local demand, activities highly segmented along gender lines), whilst men's demand for credit is high. At the same time, the women explain that they are fulfilling a social obligation by helping their kin and maintaining bonds of reciprocity which they will be able to rely on in times of need. This type of activity is lucrative, but not considered "immoral" by the community. 
In India, the principle of the self-help group also leads to parallel lending. Borrowing to onlend is relatively common, but difficult to quantify because women know that MFIs condemn this practice. Disbursement dates do not necessarily correspond to a precise need, however, and women clearly state that they do not know what to do with their money and that onlending is a way to put it to good use. Group leaders and loan officers are also active lenders, but their role is in fact much broader and includes a number of additional services. Clients use the term "adjustment" to refer to these additional services.

Adjustment is when the group leader or loan officer introduces a degree of negotiability. It is difficult to obtain reliable data on repayment rates but it is likely that on-time repayment rates are relatively low (around 50 percent), and readjustments the rule rather than the exception. Official rates of 95 percent refer to nine or 12 months. Loan officers and group leaders negotiate and jointly decide readjustments. Adjusting can involve helping clients find additional credit sources when microcredit is insufficient (in the case of certain investments or health/ceremonial expenses) or disbursement delays are too long. Adjustment may be necessary when clients have trouble repaying their loan. In the absence of an official grace period, the loan officer or group leader's occasional assistance helps the borrower "save face" and maintain credibility. This may involve facilitating access to other credit sources by acting as guarantor for dealings with private lenders or physically accompanying women to certain transactions. This assistance may also consist of direct loans. The source of funds is not clear, but it appears common that money comes from the group itself. What might appear an abuse of the system is deemed legitimate by group members as long as they have regular access to liquidity. Members even expect this practice: efficient group leaders and loan officers should be able to make loans; it is their duty!

\subsection{Group lending: Internal arrangements and the reproduction of pre-existing practices}

Once considered a major innovation, group lending is increasingly criticized as overly rigid, incapable of adapting to diverse needs, a source of hidden costs, and catering to the better-off. ${ }^{5}$ Our purpose is not to compare

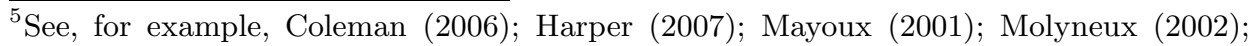
Morvant-Roux (2007); Rankin (2002); Wright (2006).
} 
individual and group loans. Either one is likely to prevail, depending on context, target population, and the objective. Instead, we aim to show how group members adjust to the group ethos and adapt it to their own habits.

In Mexico, a study of Grameen-type groups highlighted various arrangements between members (Morvant-Roux, 2007). Whilst officially individual loan amounts are determined by the MFI, the actual distribution is often very different. For example, clients tend to ask for the maximum amount even if they do not need it; the difference is given to another group member (who is in charge of repayment). "This amount must not be wasted", justify clients. In India, analyses of SHGs gave similar results: whether for internal or external loans, financial circulation within groups is more intense than the account books indicate. Such lack of transparency is deliberate: the women are all implicated in multiple and mutual debt relationships they prefer not to reveal, to avoid suspicion or jealousy.

These appropriation practices occur all the more readily, given some groups tend to mirror pre-existing social and therefore financial networks. In Mexico as in India, our observations show that borrower groups are grafted over existing debt and credit relationships. To form groups, leaders select members based on need and solvency — information only available to people already in similar financial circuits. Such mutual knowledge is exploited when the groups are created. The goal is not to contort financial supply, but rather to address the diverse needs within the same borrower group.

This appropriation process is not entirely surprising. After all, the principle of group lending is to exploit borrowers' mutual knowledge to compensate for information asymmetry. However, this process has two major implications. On the one hand, it renders financial service supply more flexible and adaptable through informal arrangements among group members. On the other, it has the potential to increase preexisting inequalities in terms of financial access. It is not unusual for group leaders themselves to be or to become moneylenders. Similarly, several quantitative studies indicate microfinance clients already have the best access to informal finance (see the example of Thailand [Coleman, 2006], Mexico [Morvant-Roux, 2006], Bangladesh [Sinha and Matin, 1998]). The ambivalence of group lending - flexibility and negotiability but also the reproduction of power relationships - is also highlighted by Susan Johnson (2007) regarding SHGs in Kenya. 


\subsection{Substitution or leverage effect?}

Ample literature demonstrates that microfinance does not substitute informal finance. Not only are microfinance clients already well integrated into informal circuits, they are agile jugglers of various forms of financing and cross-financing: microfinance is used to pay back the informal, and vice versa (Sinha and Matin, 1998; Roesch and Héliès, 2007). In rural Mexico, juggling is the rule rather than the exception. Informal lenders regularly make "bridging loans" which clients reimburse with part of their microcredit (Morvant-Roux, 2006, 2009).

These various studies analyse cross-indebtedness and the coexistence of microfinance and informal finance from a predominantly economic and financial perspective (transaction costs, flexibility, risk). We would add two further arguments.

Firstly, substitution is limited for economic and financial but also social reasons: cutting oneself off from certain sources of indebtedness would amount to social suicide. Exclusive dependence on a single provider is unfeasible - especially when the provider is a foreign institution. Such dependence would require unlimited confidence in the institution's ability to satisfy all financial needs in the long-term.

Indebtedness can occur in response to a need, but can also serve to maintain, reinforce or create a social tie. The choice of creditor can partly be explained by the desire to maintain, reinforce or create a bond, sometimes regardless of the cost: for instance, being indebted to an employer or a labour recruiter as a guarantee of getting work; being indebted to a member of the local elite to facilitate access to various forms of assistance (like governmental programmes); becoming indebted to a itinerant lender because $\mathrm{s} /$ he favours loyal clients; or quite simply becoming indebted to maintain a desired link for what it is (and not for what it can bring). Conversely, refusing a loan with a priori advantageous terms to avoid dependence is also common practice, particularly amongst certain employers, suppliers or private lenders but also with respect to the entourage or family. Some people prefer to become indebted to a costly private lender rather than "beg" from family members.

Secondly, it is our hypothesis that in certain contexts and for certain clients, microfinance not only does not substitute the informal, but has a leverage effect and thus increases informal access. Our inquiries in Southern India indicate that clients do not think in terms of substitution, but rather 
multiplication of finance sources (Guérin et al., 2009a, 2009b). Before microfinance, households juggled with two or three different options; now they have five, six or even more. There is a true leverage effect via various routes:

- The repayment of past debts (depending on the zone and population, this represents between a tenth and a quarter of microcredit use ${ }^{6}$ ) can lead to contradictory effects. Using microcredit to repay an informal lender can have a substitution effect, but it is often temporary. It also serves to preserve the borrower's reputation and recover jewels or land pledged, allowing him or her to borrow again later from the same creditor.

- Improved creditworthiness among potential creditors. The indirect role of microfinance is confirmed both by SHG members and informal financial providers. Some women say that they remain microfinance clients to maintain creditworthiness vis à vis other creditors. Even if amounts are limited compared to what they can obtain elsewhere, some women use their status as a SHG members to convince private lenders. ${ }^{7}$ Some door-to-door moneylenders explicitly state that members of SHGs are privileged clients for two reasons. Firstly, they know that the clients can request a microcredit in the event of repayment difficulties; conversely, they know that some SHG members will require their services in order to pay into their obligatory savings or for loan repayment. Studies conducted in Kerala confirm these findings (Sunil, 2005). Some door-to-door lenders even choose to visit the village on the day of the SHG meeting.

- Improved understanding of local financial markets. The financial market is diversified and dynamic. But it is also segmented and opaque. Information circulates through the SHG. (For instance, who are the "good" and the "bad" lenders? What arguments should one use during negotiations?) Women who are mobile and accustomed to borrowing stand as guarantors for others (in the case of door-to-door lenders or pawnbrokers, for example) - thus increasing their access. While such mutual assistance is common in SHGs, repayment obligations and joint responsibility reinforce this type of practice.

\footnotetext{
${ }^{6}$ These figures come from various studies carried out by the Institut Français de Pondichéry team in 2006 and 2007, which covered 1395 families, clients of various microfinance organisations, and recipients of 3457 loans.

${ }^{7}$ In Orissa, David Mosse (2005) has observed exactly the same phenomenon.
} 


\section{Conclusion}

The empirical results discussed in this article highlight the limits of the dichotomized approach to informal and formal finance based on economic criteria (transaction costs, risk, interest rates, etc.). The enmeshed relationship between informal and formal financial practices explains, in certain contexts, the overindebtedness of populations who juggle more or less deftly available finance sources. Understanding this relationship calls for studies that address all facets of finance: not just economic, but cultural, political and psychological as well.

Microfinance practitioners are not totally unaware of these practices. It is not uncommon for MFIs to use ROSCA-style expressions in advertising new products, to name their institution after the village granary, or use logos that evoke the idea of a "good" community finance institution that does its clients favours and builds relationships between individuals. At the same time, "bad finance", epitomized by "usurers" who are, incidentally, also community-based, is vilified. Many MFIs have the mission of eradicating this "bad finance", even when the latter are themselves very good MFI clients. This discourse has always resonated amongst decision makers (Bouman, 1989) and continues to do so today. For example, the World Bank report Finance For All considers financial inclusion a process that allows for the gradual suppression of informal finance, deemed both inefficient and unfair (World Bank, 2007: 66). It is true that some forms of informal finance are a source of poverty entrapment and servitude, and that microfinance can help reduce unhealthy dependency by offering contract-based working capital and risk coverage. But microfinance can also reproduce preexisting local hierarchies, for instance, when monopolized by the better-off.

More broadly, to truncate informal finance to the exploitative usurer or greedy landowner is extremely reductive. Moreover, it ignores the questions of social construction, social embeddedness and social meaning of informal finance.

Microfinance and informal finance should be considered as complementary and not as substitute. One of the main challenges of the microfinance industry is to better identify market niches where informal finance is not competitive and produces social and financial exclusion. As we have seen, people are permanently borrowing and lending tiny amounts, both for economical and social reasons. If these transactions were to be intermediated by microfinance institutions, transaction costs would be astronomical, and interest rates would be even higher. In theory, microfinance 
is supposed to make money available for medium and long-term financial needs (especially "productive" investment). Some innovations are worth noting, such as contractual savings (Churchill, 2007), commitment saving plans (Collins et al., 2009), rural leasing or warrantage (Morvant-Roux, 2009b; Bouquet et al., 2009). However these services are more the exception than the rule. Microfinance's ability to deal with risk in the long run still remains to be proved (especially in rural areas). In many cases, microcredit is still mainly used for short-term financial needs. A lot remains to be done to design financial services that could better complement the weaknesses of informal finance. This volume will certainly help to move this forward.

\section{References}

Aglietta, M and A Orléans (eds.) (1998). La monnaie souveraine. Paris: Editions Odile Jacob.

Aglietta, M and A Orléan (eds.) (1995). Souveraineté et légitimité de la monnaie. Paris: AEF/CREA.

Ardener, S (1964). The Comparative Study of Rotating Credit Associations. Journal of the Royal Anthropological Institute of Great Britain and Scotland, 94(2), 201-29.

Ardener, S and S Burman (eds.) (1996). Money-go-rounds: The Importance of Rotating Savings and Credit Associations for Women. Washington DC: Berg.

Bauer, M, J Chytilová and J Morduch (2008). Behavioral Foundations of Microcredit: Experimental and Survey Evidence From Rural India. IES Working Paper 28-2008. Institute of Economic Studies, Faculty of Social Sciences, Charles University in Pragu.

Baumann, E, L Barin, P Ould-Ahmed, P Phelinas, M Selim and R Sobel (eds.) (2008). L'argent des anthropologues, la monnaie des économistes. Paris: l'Harmattan.

Baumann, E (2003). "Vulnerability and micro-insurance. Reflections on post- adjustment Africa". In Microfinance: From Daily Survival to Social Change, Guérin and Servet (eds.), 27-43. Pondicherry: Pondy Papers in Social Sciences.

Baumann, E (1998). Chez nous, c'est $15 \%$ par mois. Coût du crédit et représentation du temps en milieu populaire à Dakar. In Rapport Exclusion et liens financiers 1997, Servet and Vallat (eds.). 35-41. Paris: AEF/Monchrestien.

Bazin, L and M Selim (2002). Monnaie: Pluralités - contradictions. Special issue of Journal des anthropologues, 90-91.

Berry, S (1995). Stable prices, unstable values: Some thoughts on monetization and the meaning of transactions in West African economies. In Money Matters: Instability, Values and Social Payments in the Modern History of West African Communities, Guyer (ed.), 299-323. London/Portsmouth (NH): Currey/Heinemann.

Bloch, M and J Parry (eds.) (1989). Money and the Morality of Exchange. Cambridge: Cambridge University Press.

Bouman, F (1995). Rotating and accumulating savings and credit associations: A development perspective. World Development, 23(3), 371-384.

Bouman, F (1994). Roscas and Ascras: Beyond the Financial Landscape. In Financial Landscape Reconstructed: The Fine Art of Mapping Development, F Bouman and O Hospes (eds.), pp. 22/1-22/10. Boulder, CO: Westview Press. 
Bouman, F (1989). Small, Short and Unsecured. Informal Rural Finance in India. New Delhi: Oxford University Press.

Bouman, F (1977). Indigenous Savings and Credit Societies in the Third World: A Message. Savings and Development, 3(4), 181-218.

Bouman, F and O Hospes (1994). Financial Landscape Reconstructed: The Fine Art of Mapping Development, Boulder, CO: Westview Press.

Bouquet, E, B Wampfler and E Ralison (2009). Rice inventory credit in Madagascar: Diversity of rural household strategies around an hybrid financial and marketing service. RUME Working Paper 2009-02.

Churchill, C (ed.) (2006). Protecting the Poor: A Microinsurance Compendium. International Labour Office, Geneva.

Coleman, BE (2006). Microfinance in Northeast Thailand: Who Benefits and How Much? World Development, 34(9), 1612-1638.

Collins, D, J Morduch, S Rutherford and O Ruthven (2009). Portfolios of the Poor: How the World's Poor Live on \$2 a Day. Princeton: Princeton University Press.

Commons, JR (1989). Institutional Economics. Its place in Political Economy. New Brunswick, London: Transaction Publishers.

Dichter, T and M Harper (eds.) (2007). What's Wrong with Microfinance? Warwickshire: Practical Action Publishing.

Fontaine, L (2008). L'économie morale. Paris: Gallimard.

Guérin, I (2006). Women and Money: Multiple, Complex and Evolving Practices. Development and Change, 37(3), 549-570.

Guérin, I, RM Venkatasubramanian and O Héliès (2009a). Microfinance, endettement et surendettement. Revue Tiers Monde, 197, 131-146.

Guérin, I and RM Venkatasubramanian (2009b). Microfinance and informal finance: Substitution or leverage effects? RUME Working Paper 2009-01.

Guyer, J (ed.) (1995). Money Matters. Instability, Values and Social Payments in the Modern History of West African Communities. London/Portsmouth (NH): Currey/ Heinemann.

Harper, M (2007). What's wrong with groups? In What's Wrong with Microfinance? Dichter T and M Harper (eds.), pp. 35-49. Warwickshire: Practical Action Publishing.

Johnson, S (2007). Institutionalized suspicion: The management and governance challenge in user-owned microfinance groups. In What's Wrong with Microfinance? Dichter T and M Harper (eds.), pp. 61-72. Warwickshire: Practical Action Publishing.

Johnson, S (2004). Gender norms and financial markets: Evidence from Keyna. World Development, 32(8), 1355-1374.

Lelart, M (1990). Les circuits parallèles de financement: État de la question. In: Lèntrepreneuriat en Afrique francophone: Culture, financement et developpment. Hénault, G and M M'Rabat (eds.), 45-65. London/Pari's: John Libbey/Aupelf-Uref.

Lelart, M (2005). De la finance informelle à la microfinance. Paris: AUF Editions, collection "Savoirs francophones".

Lont, H and O Hospes (eds.) (2004). Livelihood and Microfinance. Anthropological and Sociological Perspectives on Savings and Debt. Delft: Eburon Academic Publishers.

Malamoud, C (ed.) (1980). La dette. Paris: Ecole des Hautes Etudes en Sciences sociales (coll. Purusartha, Vol. 4).

Mauss, M (1993). Essai sur le don. In Sociologie et anthropologie, Mauss M (ed.), 145-272. Paris: PUF.

Mazzucato, V and D Niemeijer (2004). Saving arrangements in eastern Burkina Faso: An evolutionary perspective on institutional innovation. In Livelihood and Microfinance. 
Anthropological and Sociological Perspectives on Savings and Debt, Lont $\mathrm{H}$ and O Hospes (eds.), pp. 153-170. Delft: Eburon Academic Publishers.

Molyneux, M (2002). Gender and the silences of social capital. Development and Change, $33(2), 167-188$.

Morvant-Roux, S (2009). Accès au microcrédit et continuité des dynamiques d'endettement au Mexique: Combiner anthropologie et économétrie. Revue Tiers Monde, 197, 109-130.

Morvant-Roux, S (ed.) (2009b). Microfinance pour l'agriculture des pays du Sud, Rapport Exclusion et liens financiers 2008-2009. Paris: Economica.

Morvant-Roux, S (2007). Microfinance institution's clients borrowing strategies and lending groups financial heterogeneity under progressive lending: Evidence from a Mexican microfinance program. Savings and Development, 2, 193-217.

Morvant-Roux, S (2006). Processus d'appropriation des dispositifs de microfinance: Un exemple en milieu rural mexicain. Thèse de doctorat en sciences économiques, Université Lumière Lyon 2.

Mosse, D (2005). Cultivating Development. An Ethnography of Aid Policy and Practice. London: Pluto Books.

Perry, D (2002). Microcredit and women moneylenders. The shifting terrain of credit in rural Senegal. Human Organization, 61(1), 30-10.

Polanyi, K (1968). Primitive, Archaich and Modern Economies. Boston: Beacon Press.

Rankin, KN (2002). Social Capital, Microfinance and the Politics of Development. Feminist Economics, 8(1), 1-24.

Roesch, M and O Helies (2007). La microfinance: Outil de gestion du risque ou de mise en danger par sur-endettement? Revue Autrepart, 44, 119-140.

Rutherford, S (2001). The Poor and their Money. Oxford: Oxford University Press.

Sebstad, J and M Cohen (2000). Microfinance, risk management and poverty. Washington DC, USAID AIMS Project.

Servet, JM (2006). Banquiers aux pieds nus: La microfinance. Paris: Odile Jacob.

Servet, JM (1996). Community relations, individual, social and economic constraints in the savings and loans associations. In The Milano Papers, Cangiani M (ed.), Montreal/London: Black Rose Books.

Servet, JM (ed.) (1995). Épargne et liens sociaux. Études comparées d'informalités financières. Paris: AEF/AUPELF-UREF.

Servet, JM (1985). Un système alternatif d'épargne et de prêt: Les tontines africaines. Reflets et perspectives de la vie économique, 24, 13-23.

Servet, JM (1984). Nomismata. Etat et origines de la monnaie. Lyon: Presses Universitaires de Lyon.

Shipton, P (2007). The nature of entrustment. Intimacy, exchange and the sacred in Africa. New Haven \& London: Yale University Press.

Shipton, P (1995). How Gambians save: Culture and economic strategy at an ethnic crossroad. In Money matters. Instability, Values and Social Payments in the Modern History of West African Communities, Guyer J (ed.), pp. 245-277. London/Portsmouth (NH): Currey/Heinemann.

Shishir, S and S Chamala (2003). Moneylender's Positive Image. Paradigms and Rural Development. Economic and Political Weekly, 43(16), 1513-1519.

Sinha, S and I Matin (1998). Informal Credit Transactions of Microcredit Borrowers in Rural Bangladesh. IDS Bulletin, 29(4), 66-80.

Sunil, R (2005). Microfinance, informal finance and empowerment of the poor. In: Microfinance Challenges: Empowerment or Disempowerment of the Poor?, Guérin, I 
and J Palier (eds.), pp. 173-182. Pondicherry: Editions of the French Institute of Pondicherry.

Thanuja, M (2005). Relevance of microfinance and empowerment in tribal areas: A case study of Konda Reddis. In: Microfinance Challenges: Empowerment or Disempowerment of the Poor?, Guérin, I and J Palier (eds.), pp. 63-81. Pondicherry: Editions of the French Institute Pondicherry.

Toren, C (1989). Drinking cash: The purification of money through ceremonial exchange in Fiji. In Money and the Morality of Exchange, Bloch and Parry (eds.). 142-164. Cambridge: Cambridge University Press.

Villarreal, M (2004). Striving to make capital do "economic things" for the impoverished: On the issue of capitalization in rural microenterprises. In Development Intervention: Actor and Activity Perspectives, Kontinen (ed.), pp. 67-81. Helsinki: University of Helsinki.

Villarreal, M (2000). Deudas, drogas, fiado y prestado en las tiendas de abarrotes rurales. Desacatos (3), 69-88.

Vonderlack, R and M Schreiner (2002). Women, Microfinance, and Savings: Lessons and Proposals. Development in Practice, 12(5), 602-612.

World Bank (2007). Finance for All? Policies and Pitfalls in Expanding Access. A World Bank Policy Research Report. Washington DC: The World Bank.

Wright, K (2006). The darker side to microfinance: Evidence from Cajamarca, Peru. In Microfinance. Perils and Prospects, Fernando (ed.), pp. 154-172. London; Routledge.

Zelizer, V (2005). The Purchase of Intimacy. Princeton: Princeton University Press.

Zelizer, V (1994). The Social Meaning of Money. New York: Basic Books. 
